Riza Kashmiri (No. 1107), of Khan-i-Dauran (No. 1118), of Shah Daulat holding a globe (1124), may be mentioned, while two drawings of a lady at her toilet and a boy holding fruit (No. 1139) are noticeable for the effect obtained with a greater economy of line than the general style of the period would lead one to expect. Very interesting were drawings of Europeans as seen by seventeenth century Indian painters, and the unexpected Mughal copies of Dürer's "Virgin and Child" (No. 1217) and his "St. John the Evangelist" (No. 820), and a sixteenth century Indian drawing of St. Matthew.

But all these very remarkable series of Indian paintings suffer from inadequate description. More explanatory labelling would not have disturbed the general effect, and apart from the crying need for it in regard to so many of the paintings, it should be explained, for example, that the thumb ring (No. 793) was used for drawing a bow ; unnecessary inaccuracies, such as describing an obvious pheasant as a "jungle. cock" (No. 896), could easily have been avoided. Moreover, some of the miniatures with the greatest intricacy of detail (for example, No. 534) are hung too far above the eye line, and it is tiresome to find the order of pictures in the catalogue failing from time to time to correspond with the order in which they are hung.

No notice of this exhibition would be complete without mention of the admirable Mughal jade and crystal vessels in Gallery X-No. 1088 in particularand of the Girdlers' Company's Indian carpet woven for them in 1634. A good many of the modern Indian paintings could have been omitted without loss. On the other hand, it was a pleasant surprise to meet the paintings by British artists in India, the Zoffanys, including Colonel Mordaunt's Cock Match in particular, Tilly Kettle, George Chinnery, and the rest. It is a pity that in Clive's set of ivory chessmen exhibited in the same room the respective sides were mixed when they were set out.

It is to be feared that this account may read a little captiously. That is not ingratitude for such a magnificent feast of the beautiful as has been provided, but rather a feeling that it has not been cared for quite as devotedly as it deserves.

\section{J. H. HuTtoN}

\section{OBITUARIES}

Prof. E. C. C. Baly, C.B.E., F.R.S.

THE death on January 3 of Prof. E. C. C. Baly, emeritus professor of inorganic chemistry in the University of Liverpool, deprives the scientific world of a vivid and stimulating personality. He was born in 1871, his father, E. E. Baly, being an official of the Bank of England in London. He obtained his scientific training at University College, London, but instead of taking the conventional B.Sc. course he proceeded direct to the Institute of Chemistry qualification. Attracted always to research, particularly in its more romantic aspects, Baly must have found the atmosphere under Ramsay at University College very congenial. Like his chief, Baly loved an element of daring in his investigations, and generations of Liverpool students rejoiced to hear him tell the story of the discovery of the rare gases. This he did with obvious enjoyment and conscious artistry. It was at University College that he acquired his great skill as an experimenter. Indeed, his powers as a glass-blower became legendary. Even after he had suffered the loss of an eye as a result of an explosion in the laboratory, his skill was unimpaired.

Baly was one of the pioneers of spectroscopy. His work on the spectra of the rare gases was a model of its kind, and showed how the artistic side of his temperament was matched by a capacity for careful and precise work of an exhausting nature. He early showed an interest in absorption spectra in relation to chemical constitution, and a long series of papers with colleagues who later earned great distinction laid the foundations of a subject which has grown increasingly important. Baly was elected a fellow of the Royal Society in 1909. He held the post of assistant professor of chemistry and lecturer in spectroscopy during 1903-10 at University College. In 1910 he succeeded Campbell Brown as Grant professor of inorganic chemistry at Liverpool, and held the chair until his retirement in 1937.

Baly's "Spectroscopy" first appeared in 1905 and earned a great reputation as a valuable monograph. The second edition (1912) was nearly 700 pages in length, and the third edition appeared in three volumes in 1927. A fourth volume on absorption spectra of organic compounds was projected, but by that time Baly had transferred his main interest to photosynthesis, a book on which appeared in 1940 . The attempt to summarize the vast literature of spectroscopy was a tremendous task, necessitating for a chemist unusually wide reading of physical and astrophysical papers. Over many years Baly prepared reviews of the progress of inorganic chem. istry for the Annual Reports of the Chemical Society. Although many will remember him primarily as an adventurous researcher, his great contributions as a scholar should not be forgotten.

During the First World War, Baly became deputy inspector of high explosives for the Liverpool area, and at the end of the War he was awarded the C.B.E.

The post-war 'bulge' found the research laboratories at Liverpool crowded with keen ex-Servicemen, and Baly at the height of his powers. With characteristic courage he threw himself into the very difficult task of imitating in the laboratory the photosynthetic processes occurring in the living plant. In this work he was for a time joined by Prof. (now Sir Ian) Heilbron. The results of these and later researches attracted attention all over the world. They gave a powerful impetus to the continuing attack on a very complicated problem about which much still remains to be elucidated.

Baly's great personal charm, his enthusiasm and his persuasive advocacy, his skill as a musician and his feats as a mountaineer, his verve as a scientific worker and his labours on the councils of the Chemical Society, the Royal Institute of Chemistry and the British Association of Chemists will preserve his memory in many different circles. During his twentyseven years at Liverpool he gave distinguished service to the University in many capacities.

In 1902 Baly married Miss Ellen Agnes Jago, who, with four sons, survives him. R. A. Morton

\section{Sir Robert Greig}

By the death on November 29 of Sir Robert Blyth Greig, Great Britain has lost a very eminent administrator who in particular did much to further agricultural education and research. A son of George Greig, of Balcurvie in Fife, he was born in March 
1874, and his farm upbringing undoubtedly influenced his career. On leaving school he spent a short time in a bank; but farming was in his blood, and after attending classes at the University of Edinburgh, under Prof. Wallace, he went to Canada where, as a very young man, he became manager of a large ranch in Alberta.

On returning to Britain in 1897, Greig was appointed lecturer, first at Cheshire Agricultural College, and later at the Durham College of Science, Newcastleon-Tyne. In 1903 he married Maud, a daughter of the late Sir George Hunter of Newcastle. In the same year he went to the University of Aberdeen as Fordyce lecturer in agriculture, and during the next eight years took a leading part in building up the high reputation of the University Agricultural Department and the North of Scotland College of Agriculture.

In 1911 Greig was appointed inspector of agriculture under the Board of Education, but had scarcely taken up his duties when he was invited to become one of the three commissioners of the newly formed Board of Agriculture for Scotland, and in 1921 was made its chairman. In 1928, when the Board became the Department of Agriculture for Scotland, Sir Robert became its permanent secretary, and he held this post until he retired in 1934.

In the First World War he served with the Royal Scots in France, and was awarded the M.C. He was knighted in 1919. He held the honorary degrees of LL.D. (St. Andrews), and D.Sc.

Sir Robert travelled widely, visiting Canada, the United States, Australia, and various European countries on agricultural missions, and he was one of the British delegates to the Ottawa Conference. In 1929 he was president of Section M (Agriculture) of the British Association at its meetings in South Africa and, with Lady Greig and their daughter, visited Rhodesia and Kenya on the return journey. In the course of the tour he was in great demand to give talks to farmers and planters; I had the privilege of being with their party, and recall vividly the enthusiasm at these meetings.

During his official eareer, Sir Robert served on many important committees and councils, including the Carnegie Trust for the Universities of Scotland, of which he became chairman, the University Grants Committee, and the Agricultural Research Council. $\mathrm{He}$ was at one time chairman of the River Forth Conservancy Board, and was very active in the establishment of the Imperial Agricultural Bureaux, of which he became the first chairman. In 1940 he became chairman of a Scottish committee to encourage food production in private gardens and allotments, and devoted much time and energy to this work during the War.

Probably Sir Robert will be best remembered for his great services to agricultural education and research. During his period of office at the Department of Agriculture, no fewer than six research stations, now well known throughout the world, were set up in Scotland. These deal with animal nutrition, animal diseases, animal genetics, plant breeding, dairying, and soils, and their establishment was due, in great measure, to Sir Robert's foresight and enthusiasm for research. With the Macaulay Institute for Soil Research he had particularly close connexions, for he was a great personal friend of the founder, the late Mr. T. B. Macaulay, of Montreal, and he never spared himself in furthering the various schemes of agricultural betterment in Lewis and elsewhere in Scotland promoted by Mr. Macaulay. At the time of his death he was chairman of the council of management of the Macaulay Institute. His sincerity and profound knowledge of Scottish agriculture gained for him the respect and confidence of the farming community, and his friendship and encouragement meant a great deal to those of us who were closely associated with him.

When he retired at the age of sixty, Sir Robert was far too vigorous and active to settle down and do nothing. He became a director of the London, Midland and Scottish Railway, and one or two other companies, and threw himself with his usual zest into the new interests without, however, neglecting the old. Perhaps he overtaxed his strength and his death was unexpectedly sudden, but probably he would have wished it so.

It was something of a surprise to find Sir Robert was seventy-three when he died, for he remained so energetic and so youthful in spirit and appearance. His great personal charm and sense of humour made friends for him wherever he went, and those privileged to visit 'Shaws', his delightful home on the outskirts of Edinburgh, will always cherish memories of a charming host and a happy family circle. $\mathrm{He}$ is survived by Lady Greig, three sons and a daughter.

W. G. OGG

\section{Mr. H. W. Pugsley}

Herbert William Pugsley, the eminent amateur botanical systematist, died at Wimbledon on November 18. He was born at Bristol on January 24, 1868, and educated at the Grammar School there. At the age of seventeen he went to London to be coached for the Civil Service Examinations, and entered the Department of the Accountant-General of the Navy in 1886, where he remained until his retirement in 1928. After joining the Service he studied privately and obtained his B.A. degree of the University of London in 1889.

He was accustomed to spend his leave studying the floras of Great Britain and of central Europe, particularly of Switzerland, often in company with E. G. Baker and the late C. E. Salmon, who also accompanied him to North Africa in search of daffodils. Ever painstaking and critical, he soon became one of the leading British botanists-to use the general term for those engaged on the study of the flora. Of a quiet demeanour, he worked in close and friendly co-operation with the majority of his contemporaries, but had little patience with those whose identifications he considered slipshod-and occasionally said so.

Pugsley's first important work was on the British capreolate fumitories in 1902: he continued his interest in the genus, and published a monograph of Fumaria and Rupicapnos in 1919. He was also well known for his researches on Euphrasia, and his revision of the British Euphrasiece appeared in 1930. $\mathrm{He}$ was interested in narcissi and grew them in his garden for about fifty years : he wrote on the Poeticus group in 1915 and monographed the sub-genus $A j a x$ in 1933. Orchids had a continued fascination for him, and he wrote several papers on them, particularly the marsh orchids. The British robertsonian saxifrages also attracted him, and he revised the section in 1936. For many years he was engaged on a monograph of the British Hieracia. This, which he regarded as his magnum opus, is to be published by the Linnean Society, and the last batch of proofs 